\title{
əDiagnosing Surfzone Impacts on Inner-Shelf Flow Spatial Variability Using Realistic Model Experiments with and without Surface Gravity Waves
}

\author{
XiaOdong Wu, ${ }^{\mathrm{a}}$ FAlK Feddersen, ${ }^{\mathrm{a}}$ AND SARAH N. Giddings ${ }^{\mathrm{a}}$ \\ ${ }^{\text {a }}$ Scripps Institution of Oceanography, La Jolla, California
}

(Manuscript received 31 December 2020, in final form 23 April 2021)

\begin{abstract}
Rip currents are generated by surfzone wave breaking and are ejected offshore, inducing inner-shelf flow spatial variability (eddies). However, surfzone effects on the inner-shelf flow spatial variability have not been studied in realistic models that include both shelf and surfzone processes. Here, these effects are diagnosed with two nearly identical twin realistic simulations of the San Diego Bight over summer to fall, where one simulation includes surface gravity waves (WW) and the other does not (NW). The simulations include tides, weak to moderate winds, internal waves, and submesoscale processes and have surfzone width $L_{\mathrm{sz}}$ of $96( \pm 41) \mathrm{m}(\approx 1 \mathrm{~m}$ significant wave height). Flow spatial variability metrics, alongshore root-mean-square vorticity, divergence, and eddy cross-shore velocity are analyzed in an $L_{\mathrm{sz}}$ normalized cross-shore coordinate. At the surface, the metrics are consistently $(>70 \%)$ elevated in the WW run relative to NW out to $5 L_{\mathrm{sz}}$ offshore. At $4 L_{\mathrm{sz}}$ offshore, WW metrics are enhanced over the entire water column. In a fixed coordinate appropriate for eddy transport, the eddy cross-shore velocity squared correlation between WW and NW runs is $<0.5$ out to $1.2 \mathrm{~km}$ offshore or 12 time-averaged $L_{\mathrm{sz}}$. The results indicate that the eddy tracer (e.g., larvae) transport and dispersion across the inner shelf will be significantly different in the WW and NW runs. The WW model neglects specific surfzone vorticity generation mechanisms. Thus, these inner-shelf impacts are likely underestimated. In other regions with larger waves, impacts will extend farther offshore.
\end{abstract}

KEYWORDS: Coastal flows; Gravity waves; Wave breaking; Numerical analysis/modeling; Ocean models

\section{Introduction}

The coastal ocean is a conduit for the material (e.g., larvae, nutrients, and pollutants) exchange between the coastline and the open ocean (e.g., Brink 2016) and is comprised of dynamically different subregions including, from the shoreline to offshore, the surfzone, inner shelf to midshelf, and outer shelf. The surfzone extends a width of $L_{\mathrm{sz}}$ from the shoreline to the wave breakpoint location and is strongly forced by surface gravity waves (e.g., Battjes 1988). The inner shelf is seaward of the surfzone and farther offshore transitions to the midshelf. Within the inner shelf, both alongshore (e.g., Lentz 2001; Lentz and Fewings 2012) and cross-shore (Fewings et al. 2008) winds are important in driving currents. Bathymetric irregularities steer the flow (e.g., Largier 2020), favoring the generation of coastal eddies (e.g., Kirincich 2016). Submesoscale density fronts frequently develop in the inner and midshelf (Dauhajre et al. 2017; Wu et al. 2021). Inner-shelf cross-shore transport can be driven by nonlinear internal waves (e.g., Grimes et al. 2020a; Davis et al. 2020) and diurnal heating and cooling (e.g., Monismith et al. 2006). Both wind-driven Ekman and submesoscale flows are important to offshore transport of shoreline released tracer through the midshelf (Wu et al. 2020). In addition, the surface gravity wave associated Stokes drift induces Stokes-Coriolis

¿ Denotes content that is immediately available upon publication as open access.

Corresponding author: X. Wu, x1wu@ucsd.edu forces resulting in compensating Eulerian offshore-directed undertow (Lentz et al. 2008; Kirincich et al. 2009).

Within the surfzone, wave breaking generates turbulence (Feddersen 2012), vertically mixing the water column (HallyRosendahl et al. 2014), and, for obliquely incident waves, drives surfzone alongshore currents (Longuet-Higgins 1970; Feddersen et al. 1998). Surfzone vorticity is generated by finitecrest wave breaking (Peregrine 1998; Feddersen 2014), wave groups (e.g., Reniers et al. 2004; Long and Özkan-Haller 2009), or irregular bathymetry (e.g., Haller et al. 2002; Castelle and Coco 2013) which eventually leads to transient (TRC; Johnson and Pattiaratchi 2006; Spydell and Feddersen 2009) or bathymetrically controlled (BRC, Dalrymple et al. 2011; Moulton et al. 2017) rip currents. Rip currents (TRCs and BRCs) export material from $\sim 2 L_{\mathrm{sz}}$ to $\sim 4 L_{\mathrm{sz}}$ onto the inner shelf both in observations (MacMahan et al. 2010; Hally-Rosendahl et al. 2014; Brown et al. 2015; Hally-Rosendahl et al. 2015) and models (Reniers et al. 2009; Suanda and Feddersen 2015) resulting in inner-shelf eddies (flow spatial variability). Rip currents strengthen with increasing wave height or equivalently surfzone width $L_{\mathrm{sz}}$ (e.g., Haller et al. 2002; Suanda and Feddersen 2015; Moulton et al. 2017). BRC strength also depends on bathymetric variability (e.g., Reniers et al. 2007; Castelle et al. 2014; Uchiyama et al. 2017) and the offshore extent of BRCs is reduced for stronger inner-shelf alongshelf flow (Winter et al. 2014). The cross-shore extent of BRC innershelf eddies is modulated by surfzone and inner-shelf temperature differences in observations and models (Moulton et al. 2021). However, none of the cited modeling studies included realistic shelf processes such as winds, barotropic or baroclinic tides, or other inner-shelf processes. 
Rip currents have secondary effects on the stratified inner shelf induced by strong TRC mixing on the inner shelf within $2 L_{\mathrm{sz}}-4 L_{\mathrm{sz}}$ of the shoreline which have also only been studied in a few idealized models. TRC induced vertical mixing on a stratified shelf induces a cross-shore circulation cell (Kumar and Feddersen 2017b), driving cross-shelf subsurface tracer transport $\sim 10 L_{\mathrm{sz}}$ offshore (Kumar and Feddersen $2017 \mathrm{c}$ ). This circulation cell is self-similar and can be scaled by the stratification and the rip current cross-shore eddy kinetic energy flux (Grimes and Feddersen 2021). This TRC induced exchange across the inner shelf dominates over thermally driven exchange for typical Southern California conditions (Grimes et al. 2020b). These idealized modeling studies also did not consider wind, barotropic or baroclinic tidal forcing, or other important inner-shelf processes.

Idealized modeling studies of canonical inner-shelf processes (e.g., winds and tides) have not considered surfzone effects (e.g., Austin and Lentz 2002; Castelao et al. 2010; Horwitz and Lentz 2014). Furthermore, most realistic inner-shelf modeling studies do not include surfzone effects (e.g., Ganju et al. 2011; Romero et al. 2013; Dauhajre et al. 2017; Suanda et al. 2018; Dauhajre et al. 2019), with a few exceptions. The few realistic inner-shelf modeling studies which do include surfzone effects (Kumar et al. 2015, 2016; Wu et al. 2020,2021) have not examined surfzone effects on inner-shelf flow spatial variability. The range and complexity of inner-shelf processes (e.g., winds, barotropic tides, alongshore pressure gradients, internal waves, diurnal heating/cooling, bathymetric steering, submesoscale flows, and local Stokes drift-induced flows) make it challenging to separate out surfzone effects on inner-shelf flow spatial variability in realistic models as well as in observations. Identical twin realistic simulations where one simulation has waves and surfzone effects and the other without waves are required to diagnose surfzone effects on the inner shelf.

Here, we investigate the surfzone effects on inner-shelf flow spatial variability using two nearly identical realistic twin simulations spanning from the outer shelf to the shoreline using realistic bathymetry, oceanic, and atmospheric forcing. One simulation includes surface gravity waves (denoted with waves, WW) and thus a surfzone (Wu et al. 2020), whereas the other does not include waves (no waves, NW). Analysis focuses on a 3-month (from midsummer to fall) period characterized by weak to moderate winds, weak to moderate surface wave forcing, diurnal heating and cooling, active internal waves, and submesoscale frontal processes ( $\mathrm{Wu}$ et al. 2020, 2021). Surfzone effects on the inner shelf are examined by comparing metrics related to flow spatial variability between the WW and NW runs. The model configuration, regional oceanographic conditions and the analysis methods are provided in section 2. Comparisons between the WW and NW runs using the flow spatial variability metrics are presented in section 3. The role of inner-shelf processes in modulating surfzone effects on inner-shelf flow spatial variability, the effect of neglected surfzone vorticity generation mechanisms, and the surfzone effects in other regions are discussed in section 4 . Section 5 is a summary.

\section{Method}

\section{a. Model configuration}

The WW and NW runs use the Coupled Ocean-AtmosphereWave-Sediment-Transport (COAWST) model system (Warner et al. 2010; Kumar et al. 2012) with the three-dimensional, hydrostatic Regional Ocean Modeling System (ROMS) circulation model (Shchepetkin and McWilliams 2005) and the Simulating Waves Nearshore model (SWAN) (Booij et al. 1999). The NW run is not coupled to SWAN and thus has no surface gravity waves. Wu et al. (2020) provides a full description of model configuration. The model grid $\left(15 \times 36 \mathrm{~km}^{2}\right)$ spans from Punta Bandera (PB), Mexico, to the Tijuana River Estuary (TJRE) and the San Diego Bay, United States (Fig. 1a). The model grid has horizontal resolution that slowly varies from $110 \mathrm{~m}$ at the three open boundaries down to $8 \mathrm{~m}$ near the TJRE. NOAA $1 / 3$-arc-s coastal digital elevation is used for bathymetry with depth $h$ spanning from 70 to $-2 \mathrm{~m}$ (Fig. 1a) with wetting/drying enabled. The local Coriolis parameter is $f=7.8 \times 10^{-5} \mathrm{~s}^{-1}$. The vertical stretched grid has $15 s$ levels with enhanced surface and bottom resolution. The very shallow surfzone and TJRE depths (minimum of $0.25 \mathrm{~m}$ ) limit the number of vertical levels via a vertical Courant number. Vertical mixing uses a $k-\epsilon$ scheme and a logarithmic bottom drag using a bottom roughness $z_{0}=10^{-3} \mathrm{~m}$, following Kumar et al. (2015). The horizontal eddy viscosity is constant at $0.5 \mathrm{~m}^{2} \mathrm{~s}^{-1}$. NOAA/NAM surface fluxes (winds, heat, and precipitation) are used. ROMS inherits realistic oceanic forcing from three one-way nested parent runs downscaled from the California Current System to the Southern California Bight allowing remotely generated internal tides, shelf waves, and eddies to enter the domain (Wu et al. 2020). SWAN boundary conditions are provided by CDIP wave model frequency-directional wave spectra (O'Reilly et al. 2016). SWAN uses random wave dissipation of Battjes and Stive (1985) with breaking parameter $\gamma=0.5$. Note, SWAN is a wave averaged model and thus the WW run does not include finite-crest wave breaking or wave group vorticity generation mechanisms (Feddersen 2014). The grid receives small and realistic freshwater inputs at $\mathrm{PB}$ and TJRE whose locations are noted in Fig. 1a. Analysis is performed with hourly model outputs over the summer to fall transition (22 July-18 October 2015 , denoted the analysis period). Analysis focuses on a $2 \times$ $4 \mathrm{~km}^{2}$ nearshore study region (red rectangle in Fig. 1a) that has a roughly straight shoreline and is located $5.2 \mathrm{~km}$ north of $\mathrm{PB}$ and $3.0 \mathrm{~km}$ south of the TJRE mouth. The southern boundary of the nearshore study region is $7.8 \mathrm{~km}$ from the southern boundary of the model grid (Fig. 1a). The nearshore study region has a mean resolution of $(18,26) \mathrm{m}$ in the cross-shore ( $x$, positive onshore) and alongshore ( $y$, positive northward) directions, where $x=0 \mathrm{~m}$ corresponds to where time-average and alongshore-average (within nearshore study region) total water depth is zero. The vertical coordinate is represented by $z$ and $t$ is time. The bottom slope is approximately 0.04 onshore of $h=1 \mathrm{~m}, 0.015$ from $h=1 \mathrm{~m}$ to $h=10 \mathrm{~m}$, and farther offshore is $\approx 0.007$ (Fig. 2). Cross-shore and alongshore velocity components are denoted $(u, v)$, respectively. 

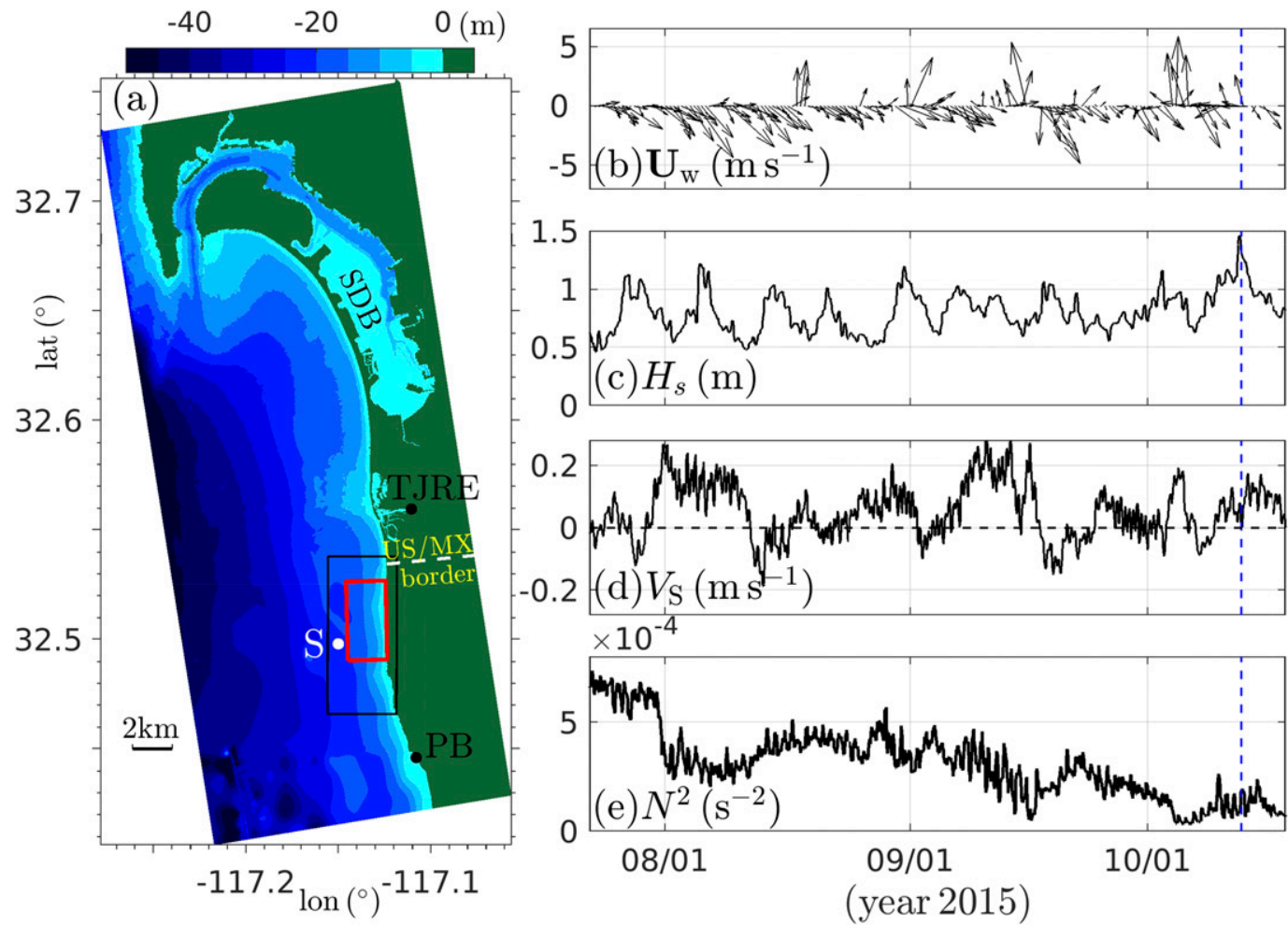

FIG. 1. (a) Model grid bathymetry (color shading) map and the nearshore study region (red rectangle). The white dot denotes site $\mathrm{S}$, and the black rectangle denotes the zoom-in domain in Fig. 2. Black dots denote the freshwater sources Punta Bandera (PB) and Tijuana River Estuary (TJRE). The San Diego Bay (SDB) and U.S.-Mexico border are also labeled. WW run time series at site $\mathrm{S}$ of (b) wind vector $\mathbf{U}_{w}$, (c) significant wave height $H_{s}$, (d) depthaveraged alongshelf current $V_{\mathrm{S}}$ (positive is northward), and (e) top-to-bottom buoyancy frequency $N^{2}$. In (b)-(e), the blue dashed line corresponds to the time step in Fig. 2.

\section{b. Regional oceanographic conditions}

On the shelf, the model solutions include realistic winddriven, barotropic tidal, internal tides, alongshelf pressure gradient driven flows, and submesoscale motions ( $\mathrm{Wu}$ et al. 2020). The barotropic tides have peak amplitude $\approx 1 \mathrm{~m}$. Conditions at shelf site $\mathrm{S}$ (22 $\mathrm{m}$ depth, Figs. 1a, 2a1) indicate the range of variability in the model forcing and response. Winds are largely southeastward directed with intermittent northward events at low $\left(<5 \mathrm{~m} \mathrm{~s}^{-1}\right)$ to moderate $\left(5-8 \mathrm{~m} \mathrm{~s}^{-1}\right)$ speeds (Fig. 1b). The significant wave height $H_{s}$ varies between 0.5 and $1.45 \mathrm{~m}$ (Fig. 1c), with typically southerly incident waves that drive northward alongshore surfzone currents (Wu et al. 2020). The site $\mathrm{S}$ alongshelf depth-averaged current $V_{\mathrm{S}}$ varies $\pm 0.2 \mathrm{~m} \mathrm{~s}^{-1}$ largely subtidally driven by alongshelf pressure gradients, but also with tidal variability (Fig. 1d). The site $\mathrm{S}$ top-to-bottom buoyancy frequency $N^{2}=-\left(g / \rho_{0}\right) \Delta \rho / \Delta z$ (Fig. 1e), representing overall stratification, decreases from summer to fall overall from $6 \times 10^{-4}$ to $1 \times 10^{-4} \mathrm{~s}^{-2}$, but also has diurnal and semidiurnal fluctuations associated with surface heating/cooling and internal tides (Wu et al. 2020).

\section{c. Analysis methods}

Within the nearshore study region, the time-varying (tides and wave-induced setup) and alongshore-varying shoreline location $x_{\mathrm{sh}}$ is defined as the location of zero total water depth ( $h+\eta=0$, where $\eta$ is the sea surface elevation). Within the nearshore study region, the alongshore averaged (denoted with \langle\rangle ) shoreline location $\left\langle x_{\mathrm{sh}}\right\rangle$ has an analysis-period time mean [ \pm standard deviation (std)] of 0 $( \pm 7) \mathrm{m}$. To account for the time-varying shoreline, a shoreline-referenced cross-shore coordinate is defined as $\tilde{x}=x-\left\langle x_{\mathrm{sh}}\right\rangle$. The wave breakpoint cross-shore location $x_{b}$ (Fig. 2a1) is defined as where the depth-limited wave breaking fraction reaches 4\% (e.g., Battjes and Stive 1985), which varies largely with incident $H_{s}$ (Fig. 1b) and the tide. The alongshore-averaged wave breakpoint location $\left\langle x_{b}\right\rangle$ has a time mean of $-96( \pm 45) \mathrm{m}$. The surfzone width $L_{\mathrm{sz}}$ is defined as the alongshore averaged difference between the shoreline and breakpoint location $L_{\mathrm{sz}}=\left\langle x_{\mathrm{sh}}\right\rangle-\left\langle x_{b}\right\rangle$ and has an analysis-period time mean (indicated with an overbar) of $\bar{L}_{\mathrm{sz}}=96( \pm 41) \mathrm{m}$.

We analyze quantities related to flow spatial variability such as relative vertical vorticity $\zeta=\partial v / \partial x-\partial u / \partial y$, divergence $\delta=$ $\partial u / \partial x+\partial v / \partial y$ and cross-shore eddy velocity $u^{\prime}$, where the prime represents the perturbation from the alongshore averaged flow,

$$
u(x, y, z, t)=\langle u\rangle(x, z, t)+u^{\prime}(x, y, z, t)
$$




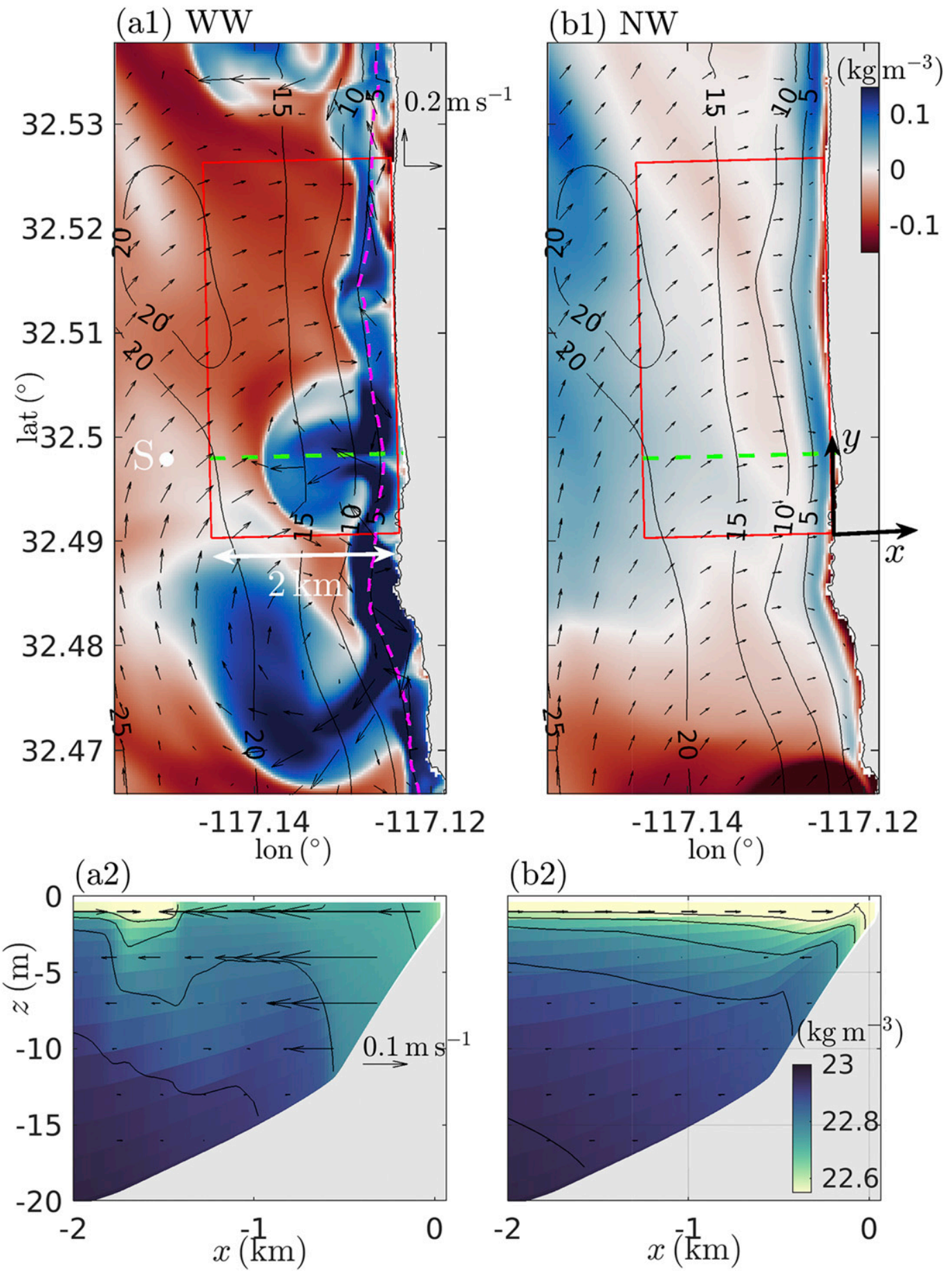

FIG. 2. (top) Snapshots of surface currents (arrows) and density anomaly (color shading, after removing the spatial mean) overlaid on bathymetry contoured at $h=[5,10,15,20] \mathrm{m}$ isobaths for the (a1) WW and (b1) NW runs. The red rectangle delineates the nearshore study region. In (a1), the magenta dashed line denotes the wave breakpoint location and the white dot denotes site S. In (b1), $(x, y)$ coordinate system is shown. (bottom) Crossshore $(x)$ and vertical $(z)$ section of cross-shore currents (arrows) and density (color shading and contoured at $0.1 \mathrm{~kg} \mathrm{~m}^{-3}$ ) along the green-dashed cross-shore transect in (a1) and (b1) for (a2) WW and (b2) NW runs, respectively. 
Vorticity and divergence are normalized by the Coriolis parameter $f$. The surfzone effects on the inner shelf are primarily diagnosed by examining the magnitude of flow spatial variability using the alongshore root-mean-square (rms) of a variable as (for vorticity),

$$
\operatorname{rms}(\zeta / f)=\left\langle\zeta^{2}\right\rangle^{1 / 2} / f
$$

focusing on $\operatorname{rms}(\zeta / f), \operatorname{rms}(\delta / f)$, and $\operatorname{rms}\left(u^{\prime}\right)$, which are functions of $x, z$, and time $t$.

\section{Results}

\section{a. Example $W W$ and $N W$ model snapshots}

Clear differences between the WW (that has a surfzone) and NW (no surfzone) runs can be seen from instantaneous flow and density snapshots, such as those shown on 2100 UTC 12 October (Fig. 2) with weak winds at $3.5 \mathrm{~m} \mathrm{~s}^{-1}$ (Fig. 1b), a relatively low tide $(\eta=-0.4 \mathrm{~m})$, and relatively large waves. At site $\mathrm{S}$, the WW run $H_{s}=1.30 \mathrm{~m}$ at this time, $7 \mathrm{~h}$ after the analysis period maximum $H_{s}=1.45 \mathrm{~m}$ (Fig. 1c), with nearnormal incident wave angle (not shown). In the nearshore study region, the wave breakpoint $x_{b}$ is just onshore of the $h=5 \mathrm{~m}$ isobath (dashed magenta line in Fig. 2a1), and $x_{b}$ and $x_{\text {sh }}$ vary coherently alongshore with a resulting large, alongshore-averaged surfzone width of $L_{\mathrm{sz}}=236 \mathrm{~m}$ (std of $32 \mathrm{~m}$ ). In this WW example, the surfzone is generally $\sim 0.2 \mathrm{~kg} \mathrm{~m}^{-3}$ denser than the shelf offshore. Rip currents eject the denser surfzone water onto the inner shelf, resulting in significant flow and density spatial variability within $1-2 \mathrm{~km}$ from shore. We focus on the rip current within the nearshore study region (at $32.5^{\circ} \mathrm{N}$ ). This rip current has an offshore directed jet, extending $1.4 \mathrm{~km}$ from the shoreline and crossing the $15 \mathrm{~m}$ isobath, which gradually widens from $0.5 \mathrm{~km}$ at $h=10 \mathrm{~m}$ to $0.9 \mathrm{~km}$ at $h=15 \mathrm{~m}$. This rip current impacts inner-shelf flow variability up to $6 L_{\mathrm{sz}}$ from the shoreline. Associated with the density front, the jet leading edge has surface divergence $\delta / f$ $\sim-10$ and, $1 \mathrm{~km}$ from shore (or $4 L_{\mathrm{sz}}$ ), surface relative vorticity $\zeta / f \sim \pm 5$ on the cyclonic (south) and anticyclonic (north) sides of the jet, and with $u^{\prime} \approx-0.3 \mathrm{~m} \mathrm{~s}^{-1}$ (not shown). Inner-shelf impacts over the vertical $(z)$ are also evident on a cross-shore transect aligned with the rip current jet (green dashed line, Fig. 2a1). Onshore of the front at $x=-1.4 \mathrm{~km}, u$ is offshore directed within the upper $5 \mathrm{~m}$ (Fig. 2a2), the upper $5 \mathrm{~m}$ averaged velocity decreases from $0.2 \mathrm{~m} \mathrm{~s}^{-1}$ at $x=-0.5 \mathrm{~km}$ to $0.05 \mathrm{~m} \mathrm{~s}^{-1}$ at the front, and stratification is weak throughout the water column, reflecting strong rip current mixing (e.g., Kumar and Feddersen 2017b; Uchiyama et al. 2017). Just offshore of the front, near-surface flow is weakly onshore and the upper $5 \mathrm{~m}$ is strongly stratified with vertical density difference of $0.2 \mathrm{~kg} \mathrm{~m}^{-3}$. At this same time, the NW run shelf circulation and density field is strikingly different (Figs. 2b1,b2). The NW surface density and flow variability is weaker and smoother than WW. The surface shelf flows for $h>5 \mathrm{~m}$ are roughly alongshore uniform which, in $h<5 \mathrm{~m}$, weaken due to the shoreline barrier and bottom friction (Fig. 2b1). The maximum NW near-surface $\zeta / f$ and $\delta / f$ are both $\approx 2$ in depths $<5 \mathrm{~m}$ with associated $u^{\prime}=0.02 \mathrm{~m} \mathrm{~s}^{-1}$ (not shown), values far weaker and confined to the shoreline relative to WW. On the cross-shore transect (green dashed, Fig. 2b1), NW currents have a mode-1 baroclinic structure with weak $\left(\sim 0.03 \mathrm{~m} \mathrm{~s}^{-1}\right)$ onshore flow over the upper $3 \mathrm{~m}$ and much weaker $\left(\sim 0.005 \mathrm{~m} \mathrm{~s}^{-1}\right)$ offshore flow underneath (Fig. 2b2). The water column is well stratified over the transect to within $200 \mathrm{~m}$ of the shoreline.

Within the nearshore study region, the WW and NW example differences in inner-shelf flow spatial variability are contextualized with alongshore rms (section 2c) of surface vorticity, divergence, and cross-shore eddy velocity for this case example (Fig. 2). For example, between $1 \mathrm{~km}$ and $1.4 \mathrm{~km}$ from the shoreline (about $4 L_{\mathrm{sz}}-6 L_{\mathrm{sz}}$ ), the $\mathrm{WW} \operatorname{rms}(\zeta / f) \approx 3$, $\operatorname{rms}(\delta / f) \approx 4$ and $\operatorname{rms}\left(u^{\prime}\right) \approx 0.065 \mathrm{~m} \mathrm{~s}^{-1}$, indicating strong eddy variability and divergent motions-associated with the submesoscale. In contrast, over the same region $(1-1.4 \mathrm{~km}$ from shore $)$, the $\mathrm{NW} \operatorname{rms}(\zeta / f) \approx 0.66$ and $\operatorname{rms}(\delta / f) \approx 0.3$, far weaker ( 6 times and 12 times, respectively) than WW, and their values $<$ 1 indicate different dominant flow dynamics. The $\mathrm{NW} \operatorname{rms}\left(u^{\prime}\right) \approx$ $0.005 \mathrm{~m} \mathrm{~s}^{-1}$ is over 10 times smaller than for WW. Overall, for this case example, clear surfzone effects on the inner shelf are present to $6 L_{\mathrm{sz}}$ within the nearshore study region.

\section{b. WW and NW run inner-shelf flow spatial variability statistics}

The WW run example has dramatically more flow spatial variability (impacting vorticity, divergence, and eddy crossshore velocity) than the NW run, inducing significant density variation (Fig. 2). Here, the WW and NW run differences in flow spatial variability metrics $\zeta, \delta$, and $u^{\prime}$ are examined statistically over the analysis period, quantifying the surfzone effects on the inner shelf. At each time step surface $\operatorname{rms}(\zeta / f)$, $\operatorname{rms}(\delta / f)$, and $\operatorname{rms}\left(u^{\prime}\right)$ are interpolated onto a surfzone-width normalized offshore coordinate $\tilde{x} / L_{\mathrm{sz}}$, as $L_{\mathrm{sz}}$ is a key length scale for inner-shelf rip current effects in idealized models (Suanda and Feddersen 2015), and subsequently the temporal median (50\%), 30\%, and 70\% values are calculated (Fig. 3). In addition, at a selected cross-shore location $\tilde{x} / L_{\mathrm{sz}}=-4$, the temporal median $(50 \%), 30 \%$, and $70 \%$ values of flow metrics are calculated over the nondimensional vertical $z^{\prime} /(h+\eta)$, where the vertical coordinate is referenced to the sea surface $\eta$, i.e., $z^{\prime}=z-\eta$ (Fig. 4).

We first examine the normalized cross-shore structure of rms flow spatial variability metrics at the surface (Fig. 3). At the surfzone boundary $\left(\tilde{x} / L_{\mathrm{sz}}=-1\right)$, the WW median $\operatorname{rms}(\zeta / f)^{(\mathrm{ww})}=18$, substantially greater than the NW mean $\operatorname{rms}(\zeta / f)^{(n w)}=3.5$ (Fig. 3a), as expected near the surfzone boundary. The median $\operatorname{rms}(\zeta / f)^{(\mathrm{ww})}$ decays offshore rapidly to about $\tilde{x} / L_{\mathrm{sz}}=-3$ and more slowly farther offshore. In contrast, $\operatorname{rms}(\zeta / f)^{(\mathrm{nw})}$ decays slowly offshore throughout so that by $\tilde{x} / L_{\mathrm{sz}}=-8$ the $\mathrm{WW}$ and $\mathrm{NW} \operatorname{rms}(\zeta / f) \approx 0.75$ with similar, largely overlapping distributions (Fig. 3a). For WW, the crossshore structure of $\operatorname{rms}(\delta / f)$ is analogous to vorticity, with a $\tilde{x} / L_{\mathrm{sz}}=-1$ maximum of $\operatorname{rms}(\delta / f)^{(\mathrm{ww})}=3.5$ and offshore decay that largely merges with the nearly cross-shore uniform $\operatorname{rms}(\delta / f)^{(\text {nw) }} \approx 1$ by $\tilde{x} / L_{\mathrm{sz}}=-8$ (Fig. 3b). In the intermediate zone of $-5<\tilde{x} / L_{\mathrm{sz}}<-3, \operatorname{rms}(\zeta / f)^{(\mathrm{ww})}$ and $\operatorname{rms}(\delta / f)^{(\mathrm{ww})}$ are usually elevated over $\operatorname{rms}(\zeta / f)^{(\mathrm{nw})}$ and $\operatorname{rms}(\delta / f)^{(\mathrm{nw})}$, respectively. For example, at $\tilde{x} / L_{\mathrm{sz}}=-4$, the median $\operatorname{rms}(\zeta / f)^{(\mathrm{ww})}=$ 

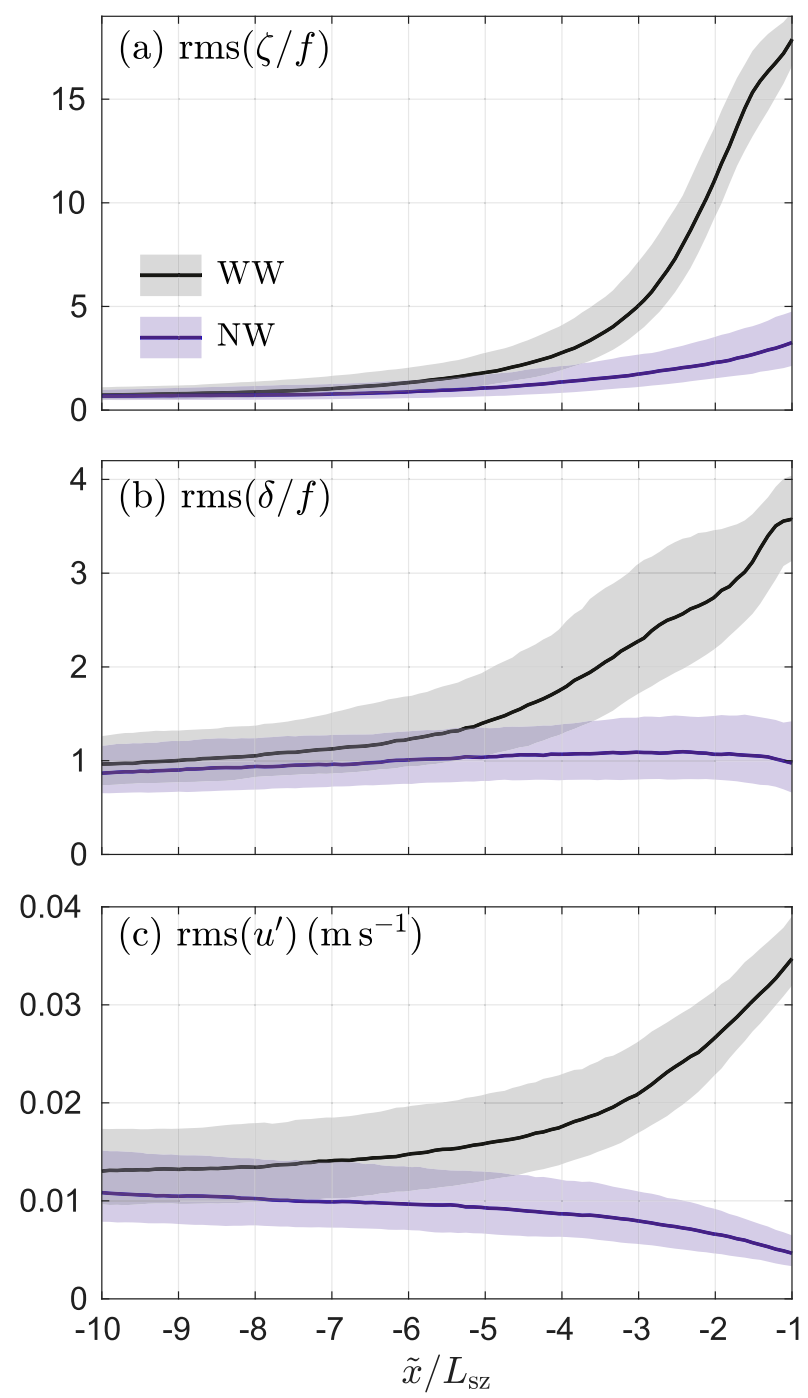

FIG. 3. The temporal median (solid) and 30\%-70\% (shading) of the surface alongshore rms (a) normalized vertical vorticity $\operatorname{rms}(\zeta / f)$, (b) normalized divergence $\operatorname{rms}(\delta / f)$, and (c) eddy crossshore velocity $\operatorname{rms}\left(u^{\prime}\right)$ vs normalized cross-shore coordinate $\tilde{x} / L_{\mathrm{sz}}$ for the WW (black) and NW (blue) runs.

2.8 whereas $\operatorname{rms}(\zeta / f)^{(\mathrm{nw})}=1.4$ and $\operatorname{rms}(\zeta / f)^{(\mathrm{ww})}>\operatorname{rms}(\zeta / f)^{(\mathrm{nw})}$ $82 \%$ of the time (Fig. 3a). Similarly, at $\tilde{x} / L_{\mathrm{sz}}=-4$, the median $\operatorname{rms}(\delta / f)^{(\mathrm{ww})}=1.8$ whereas the median $\operatorname{rms}(\zeta / f)^{(\mathrm{nw})}=1.0$, and $\operatorname{rms}(\delta / f)^{(\mathrm{ww})}>\operatorname{rms}(\delta / f)^{(\mathrm{nw})} 81 \%$ of the time (Fig. 3b). The cross-shore structures of WW and $\mathrm{NW} \mathrm{rms}\left(u^{\prime}\right)$ are qualitatively similar to the vorticity and divergence metrics (Fig. 3c). The $\operatorname{rms}\left(u^{\prime}\right)^{(\mathrm{ww})}$ decays strongly offshore from a $\tilde{x} / L_{\mathrm{sz}}=-1$ maximum of $\operatorname{rms}\left(u^{\prime}\right)^{(\mathrm{ww})}=0.035 \mathrm{~m} \mathrm{~s}^{-1}$ down to $\operatorname{rms}\left(u^{\prime}\right)^{(\mathrm{ww})}=$ $0.013 \mathrm{~m} \mathrm{~s}^{-1}$ at $\tilde{x} / L_{\mathrm{sz}}=-10$. In contrast, $\operatorname{rms}\left(u^{\prime}\right)^{(\mathrm{nw})}$ is largely $0.01 \mathrm{~m} \mathrm{~s}^{-1}$ and decays slightly toward the shoreline (Fig. 3c) due to no surfzone forcing and shallow water friction. Over $-6<\tilde{x} / L_{\mathrm{sz}}<-3$, the $\operatorname{rms}\left(u^{\prime}\right)^{(\mathrm{ww})}$ is consistently larger than $\operatorname{rms}\left(u^{\prime}\right)^{(\mathrm{nw})}$. For example, at $\tilde{x} / L_{\mathrm{sz}}=-4$, mean $\operatorname{rms}\left(u^{\prime}\right)^{(\mathrm{ww})}=$ $0.018 \mathrm{~m} \mathrm{~s}^{-1}$ whereas the median $\operatorname{rms}\left(u^{\prime}\right)^{(\mathrm{nw})}=0.009 \mathrm{~m} \mathrm{~s}^{-1}$, and $\operatorname{rms}\left(u^{\prime}\right)^{(\mathrm{ww})}>\operatorname{rms}\left(u^{\prime}\right)^{(\mathrm{nw})} 90 \%$ of the time.
These results show that, over the 3-month analysis period, the temporal median of the three rms flow spatial variability metrics at the surface are consistently elevated out to $\tilde{x} / L_{\mathrm{sz}} \approx-5$. We define the region where the surfzone consistently affects the inner shelf as where the WW metric exceeds the NW metric $\geq$ $70 \%$ of the time. This location is similar for all three metrics at the surface and is bounded by $\tilde{x} / L_{\mathrm{sz}}=-5.5$ for $\operatorname{rms}(\zeta / f)$ and $\operatorname{rms}(\delta / f)$ and is bounded by $\tilde{x} / L_{\mathrm{sz}}=-6.3$ for $\operatorname{rms}\left(u^{\prime}\right)$, confirming that the region onshore of $\tilde{x} / L_{\mathrm{sz}}=-5$ is that of consistent surfzone impacts on inner-shelf flow spatial variability. Of course, surfzone effects can and do extend farther offshore such as in the case example in Fig. 2a, but do not do so consistently.

Next, we examine the vertical structure of the WW and NW flow spatial variability metrics at $\tilde{x} / L_{\mathrm{sz}}=-4$, a location relatively far offshore where the surface WW metrics are consistently larger than NW. For reference, at $\tilde{x} / L_{\mathrm{sz}}=-4$, the water depth $(h+\eta)$ varies from $6.9( \pm 2.3) \mathrm{m}$, and has average vertical grid resolution of $\Delta z=0.15 \mathrm{~m}$ at surface and $\Delta z=$ $0.5 \mathrm{~m}$ near-bed. The WW median $\operatorname{rms}(\zeta / f)$ decreases from near-surface $\operatorname{rms}(\zeta / f)^{(\mathrm{ww})}=2.7$ to near-bed $\operatorname{rms}(\zeta / f)^{(\mathrm{ww})}=2.0$ (Fig. 4a). In contrast the NW $\operatorname{rms}(\zeta / f)$ has subsurface maxima $\approx 1.8$ at $z^{\prime} /(h+\eta)=-0.6$, resulting in $\mathrm{WW}$ to $\mathrm{NW} \operatorname{rms}(\zeta / f)$ median ratio of 1.4 . The $\mathrm{WW}$ to $\mathrm{NW} \operatorname{rms}(\zeta / f)$ ratio is $>1$ more than $70 \%$ of the time everywhere in the water column. The WW median $\operatorname{rms}(\delta / f)^{(\mathrm{ww})}$ varies from near-surface $\approx 1.7$ to near-bed $\approx 1.3$ (Fig. $4 \mathrm{~b}$ ). The NW median $\operatorname{rms}(\delta / f)$ varies similarly in the vertical and is within $0.5-0.7$ of $\operatorname{rms}(\delta / f)^{(\mathrm{ww})}$. The WW and NW distributions overlap somewhat, but everywhere in the water column the WW to NW rms $(\delta / f)$ ratio is $>1$ more than $70 \%$ of the time. The $\operatorname{rms}\left(u^{\prime}\right)^{(w w)}$ decays with depth from 0.017 to $0.010 \mathrm{~m} \mathrm{~s}^{-1}$ whereas $\operatorname{rms}\left(u^{\prime}\right)^{(\mathrm{nw})}$ is more vertically uniform varying from 0.007 to $0.008 \mathrm{~m} \mathrm{~s}^{-1}$ (Fig. 4c). The median WW to NW rms $\left(u^{\prime}\right)$ ratio decreases from 2 near-surface to 1.3 near-bed. Throughout most of the water column the $\operatorname{rms}\left(u^{\prime}\right)^{(\mathrm{ww})} / \mathrm{rms}\left(u^{\prime}\right)^{(\mathrm{nw})}>1$ more than $80 \%$ of the time. Thus, the larger WW relative to NW surface flow spatial variability metrics at $\tilde{x} / L_{\mathrm{sz}}=-4$ are also largely consistent throughout the water column (Fig. 4), although WW and NW median flow metrics are more similar with increased distribution overlap near the bed. Although the shallow portion of the inner shelf is relatively turbulent and the vertical resolution is enhanced near surface and bed, the vertical structure of the flow spatial variability metrics may be affected by vertical grid resolution. The differences over the water column in WW and NW flow spatial variability metrics increase rapidly onshore (not shown), as at the surface (Fig. 3).

\section{c. WW and NW eddy cross-shore velocity correlations in a fixed cross-shore coordinate}

Surfzone effects on the inner shelf out to $5 L_{\mathrm{sz}}$ are consistently seen in the magnitude (root-mean-square) of the metrics $\zeta / f, \delta / f$, and $u^{\prime}$ representing flow spatial variability. However, these metrics are in a reference frame tied to $L_{\mathrm{sz}}$. Cross-shore eddy tracer transport at a fixed location (i.e., $\overline{u^{\prime} C^{\prime}}$, where $C$ is a generic tracer), depends both on $u^{\prime}$ magnitude and its correlation with $C^{\prime}$. At a fixed cross-shore location, a nonunitary correlation between WW and NW $u^{\prime}$ suggests differences in eddy cross-shore transport events and in Lagrangian tracer 

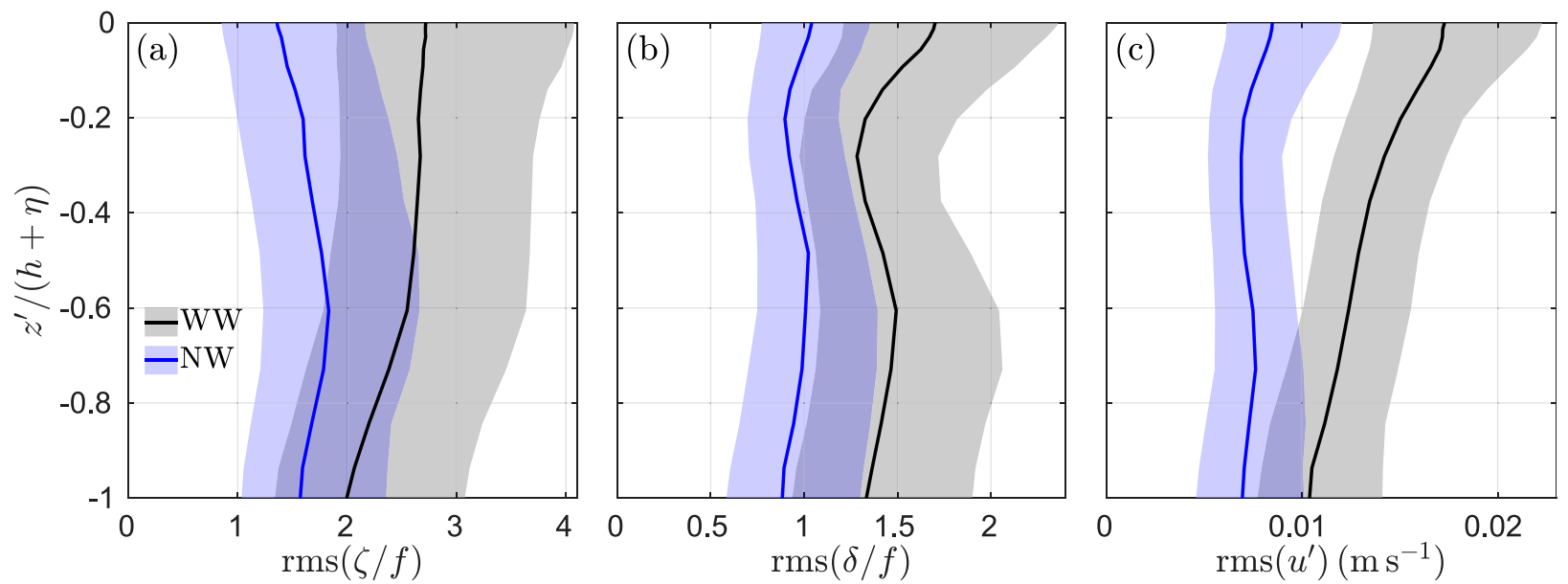

FIG. 4. The temporal median (solid) and 30\%-70\% (shading) of the surface alongshore rms (a) vorticity $\operatorname{rms}(\zeta / f)$, (b) divergence $\operatorname{rms}(\delta / f)$, and (c) eddy cross-shore velocity $\operatorname{rms}\left(u^{\prime}\right)$ vs normalized vertical coordinate $z^{\prime} /(h+\eta)$ (where $\left.z^{\prime}=z-\eta\right)$ at $\tilde{x} / L_{\mathrm{sz}}=-4$ for the WW (black) and NW (blue) runs.

evolution, even if the NW and WW have similar $\operatorname{rms}\left(u^{\prime}\right)$. As eddy transport is calculated at a fixed location (e.g., with an ADCP and mooring), we examine the surface $u^{\prime}$ squared correlation $r^{2}$ between WW and NW runs in a fixed coordinate system, not a $L_{\mathrm{sz}}$ normalized (moving) coordinate system. Within $0.2 \mathrm{~km}$ of shore (or $\approx 2 \bar{L}_{\mathrm{sz}}$, where the time-average $\left.\bar{L}_{\mathrm{sz}}=96 \mathrm{~m}\right)$, the $u^{\prime}$ squared correlation $r^{2}$ between WW and NW runs is near zero (Fig. 5), as expected near the surfzone, where strong surfzone currents are driven in the WW run. Farther offshore, the $u^{\prime} r^{2}$ between WW and NW runs increases quasilinearly to about $r^{2}=0.46$ at $x=-1.2 \mathrm{~km}$ (or $\approx 12 \bar{L}_{\mathrm{sz}}$, Fig. 5), indicating significant differences in timing or phase of $u^{\prime}$ between WW and NW runs that most extreme near surfzone and decrease offshore yet remain significant $1 \mathrm{~km}$ offshore. The cross-shore structure of the squared correlations between WW and NW for $\zeta / f$ and $\delta / f$ are similar (not shown). Thus, although the NW and WW eddy cross-shore velocities have largely similar magnitudes far offshore (Fig. 3c), their significant nonzero correlation at $12 \bar{L}_{\mathrm{sz}}$ (Fig. 5) indicates that, cross-shore eddy transport events likely have different timings even $1 \mathrm{~km}$ offshore for a model that includes surfzone effects relative to one that does not.

\section{Discussion}

\section{a. Effect of inner-shelf processes on $W W$ and $N W$ metrics}

We have statistically demonstrated surfzone effects on the inner shelf out to $5 L_{\mathrm{sz}}$ using differences between the modeled WW and NW magnitude metrics of flow spatial variability (vorticity, divergence, and eddy cross-shore velocity, Figs. 3, 4) as well as the eddy cross-shore velocity squared correlation between the WW and NW runs (Fig. 5). At $\tilde{x} / L_{\mathrm{sz}}=-4$ the WW surface flow spatial variability metrics are $>80 \%$ likely to be larger than for NW. However, occasional times exist where, for example, $\operatorname{rms}(\zeta / f)^{(\mathrm{nw})}>\operatorname{rms}(\zeta / f)^{(\mathrm{ww})}$ at $\tilde{x} / L_{\mathrm{sz}}=-4$. Various inner-shelf mechanisms, for example, inner-shelf eddies or mean flow, may impact the cross- shore distance that surfzone ejected vorticity can impact the inner-shelf. Here, we examine the effect of hourly depthaveraged alongshelf velocity at location $\mathrm{S}, V_{\mathrm{S}}$ (Fig. 1d), on the ratio $\operatorname{rms}(\zeta / f)^{(\mathrm{ww})} / \mathrm{rms}(\zeta / f)^{(\mathrm{nw})}$ at the normalized cross-shore location $\tilde{x} / L_{\mathrm{sz}}=-4$ (Fig. 6). For weak $\left|V_{\mathrm{S}}\right|<0.1 \mathrm{~m} \mathrm{~s}^{-1}$, the median $\operatorname{rms}(\zeta / f)^{(\mathrm{ww})} / \mathrm{rms}(\zeta / f)^{(\mathrm{nw})}$ is always $\geq 1.7$ and the $\operatorname{rms}(\zeta / f)^{(\mathrm{ww})} / \mathrm{rms}(\zeta / f)^{(\mathrm{nw})}$ is very often $(87 \%)$ greater than one. However, the median $\operatorname{rms}(\zeta / f)^{(\mathrm{ww})} / \mathrm{rms}(\zeta / f)^{(\mathrm{nw})}$ decreases with increasing $V_{\mathrm{S}}$ from a maximum of 2.7 at $V_{\mathrm{S}}=0.035 \mathrm{~m} \mathrm{~s}^{-1}$ to $\approx 1.25$ for $V_{\mathrm{S}}=0.25 \mathrm{~m} \mathrm{~s}^{-1}$ with narrowing ratio distributions. For $V_{\mathrm{S}} \geq 0.2 \mathrm{~m} \mathrm{~s}^{-1}, \operatorname{rms}(\zeta / f)^{\mathrm{ww}} / \mathrm{rms}(\zeta / f)^{\mathrm{nw}}>1$ only $62 \%$ of the time, or close to equal probability. Thus, the cross-shore extent of surfzone effects on the inner shelf are reduced for stronger alongshelf flows. Note, large $V_{\mathrm{S}}$ is relatively uncommon

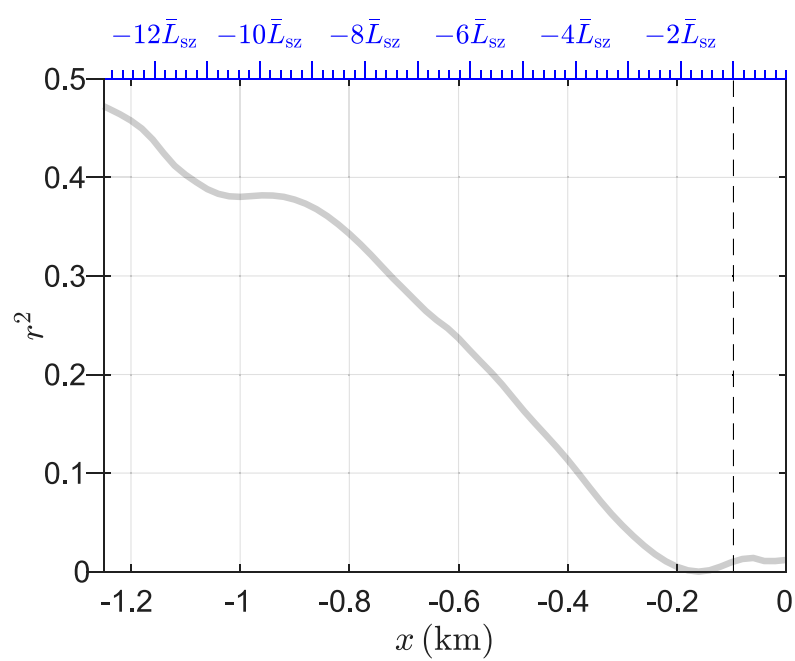

FIG. 5. Squared correlation $r^{2}$ between the WW and NW surface eddy cross-shore velocity $u^{\prime}$ vs cross-shore distance $x$ (on top as in time-mean surfzone width $\bar{L}_{\mathrm{sz}}$ coordinates). At each $x$ location, $r^{2}$ is calculated over time and the alongshore. 


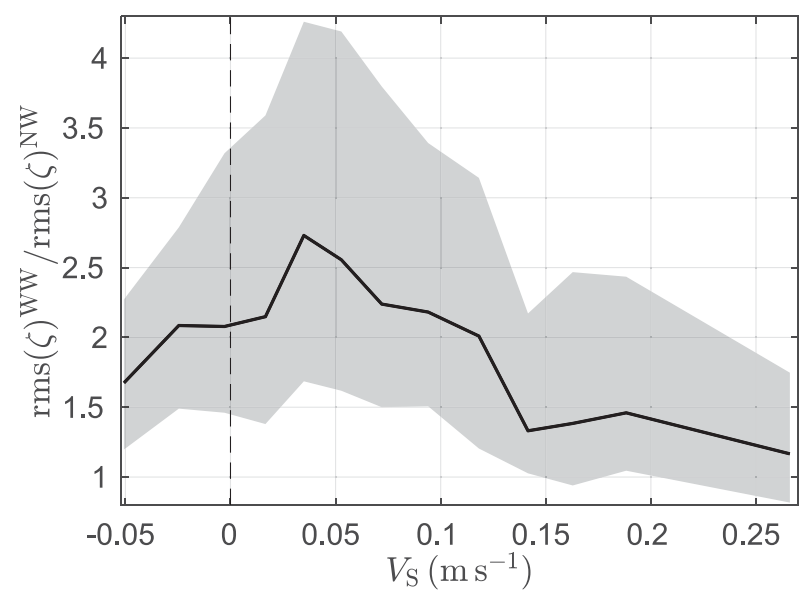

FIG. 6. The binned median (solid) and 30\%-70\% (shading) of the WW to NW surface alongshore rms vorticity ratio $\operatorname{rms}(\zeta)^{(\mathrm{ww})} / \mathrm{rms}(\zeta)^{(\mathrm{nw})}$ at $\tilde{x} / L_{\mathrm{sz}}=-4$ vs the depth-averaged alongshore current at location $\mathrm{S}, V_{\mathrm{S}}$.

(Fig. 1d). This result is consistent with alongshelf flows reducing the offshore extent of observed and modeled drifters released within a BRC (Winter et al. 2014). Other shelf processes may impact the relative strength of the WW to NW flow spatial variability metrics. For example, a warmer surfzone relative to inner shelf leads to farther offshore rip current propagation in both observations and models (Moulton et al. 2021). In addition, nonlinear internal waves (NLIW) are active in this region's inner shelf (e.g., Grimes et al. 2020a), can propagate to the surfzone (Sinnett et al. 2018), and have an associated surface horizontal divergence. The relative importance of rip current induced surface divergence (e.g., Fig. 2a1) would be reduced during times of NLIW events resulting in smaller ratio of $\operatorname{rms}(\delta / f)^{(\mathrm{ww})} / \mathrm{rms}(\delta / f)^{(\mathrm{nw})}$.

\section{b. Surfzone vorticity generation mechanisms}

The COAWST model with coupled ROMS and SWAN does not have wave group (e.g., Long and Özkan-Haller 2009) or finite-crest length breaking (Clark et al. 2012) surfzone vorticity generation mechanisms that generate transient rip currents (TRCs) particularly at relatively short $(10-50 \mathrm{~m})$ alongshore length scales (Feddersen 2014). Instead surfzone vorticity is generated through alongshore bathymetric variations (BRCs) and shear instabilities (e.g., Noyes et al. 2005). The model horizontal eddy viscosity of $0.5 \mathrm{~m}^{2} \mathrm{~s}^{-1}$ is sufficiently small to allow shear instabilities to occur (Özkan-Haller and Kirby 1999). A model study that resolves both BRCs and TRCs reveals that both of them are important contributors to the total eddy kinetic energy (i.e., $\left\langle u^{\prime 2}\right\rangle+\left\langle v^{\prime 2}\right\rangle$ ) (O'Dea et al. 2021). As the wave group and finite-crest length breaking vorticity generation mechanisms that induce TRCs are not included, the model results here likely represent a lower bound on surfzone effects on the inner shelf. For example, for similar incident waves, an idealized, TRC-resolving COAWST simulation had $\operatorname{rms}(\zeta / f) \approx 40$ at $\tilde{x} / L_{\mathrm{sz}}=-2$ (Kumar and Feddersen 2017a), significantly larger than the median $\operatorname{rms}(\zeta / f)^{(\text {ww) }}=11$ (Fig. 3a) or the $90 \%$ value of 18 .
The nearshore study region (red box in Fig. 2) was chosen for its relatively alongshore uniform bathymetry. However, offshore of the surfzone, bathymetric variations are sufficient to induce, via wave refraction, alongshore variations in the breakpoint (dashed magenta in Fig. 2a1) that induce convergent surfzone alongshore currents and BRCs (Long and Özkan Haller 2005). In addition, bathymetry within the surfzone is alongshore variable as quantified by the metric $\left\langle h^{2}\right\rangle /\langle h\rangle^{2} \approx 0.12$, a value indicating alongshore nonuniform circulation (Ruessink et al. 2001; Feddersen and Guza 2003) which can induce BRCs (Apotsos et al. 2008), even for a uniform incident wave field.

Last, within the nearshore study region, the cross-shore model resolution is relatively coarse, on average within the nearshore study region $\Delta x=18 \mathrm{~m}$, and as such the model resolution in the surfzone is limited. This model resolution was a compromise between spanning more than $10 \mathrm{~km}$ offshore (Fig. 1a) and resolving the surfzone (Fig. 2a1). On the inner shelf, increased model resolution has been shown to significantly enhance submesoscale processes and cross-shelf transport (Dauhajre et al. 2019). Increased model horizontal resolution within the nearshore study region also is likely to enhance the surfzone effects on the inner shelf as diagnosed by the flow spatial variability metrics. The vertical grid resolution is also limited due to the shallow water depths and COAWST is hydrostatic. However, these limitations are required to effectively simulate a region as large as our $15 \times 36 \mathrm{~km}^{2}$ model domain (Fig. 1a).

\section{c. Other surfzone effects on the inner shelf}

As rip currents are ejected from the surfzone onto the inner shelf, inducing vorticity and eddies on the inner shelf, we have examined the magnitude of three flow spatial variability metrics, related to eddies and eddy transport, and their difference between the WW and NW runs. As the $\operatorname{rms}\left(u^{\prime}\right)$ varies strongly (i.e., is inhomogeneous) cross-shore, the cross-shore extent of eddy transport is limited as long-time dispersion is subdiffusive in a spatially inhomogeneous eddy field (Spydell et al. 2019). Rip currents can have other impacts on the inner shelf. The enhanced vertical mixing within TRCs on the stratified inner shelf induces a cross-shore circulation cell transporting subsurface low stratified water and tracer $\sim 10 L_{\mathrm{sz}}$ offshore in $\sim 12 \mathrm{~h}$ for incident $H_{s}=1 \mathrm{~m}$ (Kumar and Feddersen 2017c). This mechanism is self-similar, depends on stratification and rip current eddy kinetic energy flux, and offshore of $\sim 4 L_{\mathrm{sz}}$ is far more effective at cross-shelf transport than eddy transport (Grimes and Feddersen 2021). However, note that the COAWST model does not include TRC effects. BRCs also enhance vertical mixing (Uchiyama et al. 2017), but their effect on inner-shelf stratification is not yet studied. The surfzone may have many other effects on the inner shelf. For example, a rip current jet may refract an incident inner-shelf NLIW resulting in alongshore variable NLIW dissipation and tracer transport. Rip current induced density gradients may seed submesoscale density fronts, particularly in a preexisting shelf strain field (Wu et al. 2020). On a realistic inner shelf with overlapping processes, diagnosing such effects requires separating out internal waves, diurnal forced oscillations (Grimes et al. 2020b), and rip current forced processes, which will be the subject of future work. 


\section{d. Effects on the inner shelf in other regions}

We have shown consistent surfzone effects on the inner shelf out to $5 L_{\mathrm{sz}}$ from the shoreline for the magnitude of flow spatial variability metrics (Fig. 3). Thus, ocean models that do not include surfzone processes will underrepresent eddy processes within this region. During this 3-month-long simulation, the significant wave height $H_{s}$ was fairly small, $\leq 1 \mathrm{~m}$ the majority ( $85 \%$ ) of the time and the maximum wave height $H_{s}=1.45 \mathrm{~m}$ (Fig. 1b). The resulting $\bar{L}_{\mathrm{sz}}=96 \mathrm{~m}$ (and mostly $<150 \mathrm{~m}$ ). With surfzone effects to $5 L_{\mathrm{sz}}$, this implies effects on average out to $500 \mathrm{~m}$ (mostly $<750 \mathrm{~m})$ from shore. In many other regions, the incident $H_{s}$ is much larger. For example, during wintertime on the Oregon U.S. coast, incident $H_{s}$ is very often $\geq 3 \mathrm{~m}$ and can be as large as $9 \mathrm{~m}$ (Seymour et al. 2016). Assuming a planar bathymetry so that $L_{\mathrm{sz}}$ increases linearly with $H_{s}$, this suggests that surfzone effects on the inner shelf can extend multiple $\mathrm{km}$ offshore during such large waves, whose inner-shelf impacts are not understood. Typical realistic coastal ocean circulation models that neglect surfzone effects use a horizontal grid resolution of $200 \mathrm{~m}$ (Romero et al. 2013; Suanda et al. 2017; Kumar et al. 2019) to $75 \mathrm{~m}$ (Dauhajre et al. 2017), and so multiple near-shoreline model grid points will be impacted, affecting transport and dispersion of larvae, pollutants, or other tracers across the inner-shelf and surfzone region.

\section{Summary}

Surfzone-generated rip currents eject vorticity onto the inner shelf, inducing flow spatial variability. This work investigates the surfzone effects on inner-shelf flow spatial variability using two nearly identical twin realistic simulations of the San Diego Bight over the summer to fall transition. One simulation (WW) uses a wave-current coupled model whereas the other (NW) does not include waves. The 3-month analysis period is characterized by weak to moderate winds, weak to moderate (usually $<1 \mathrm{~m}$ ) incident significant wave height, diurnal heating and cooling, active internal waves, and submesoscale frontal processes. An example of the modeled density and flow snapshots show dramatic differences between the WW and NW runs, as the WW run has rip currents that extend up to six surfzone widths $L_{\mathrm{sz}}$ from the shoreline inducing flow spatial variability. Flow spatial variability metrics, defined as alongshore root-mean-square vorticity, divergence, and eddy crossshore velocity, are analyzed in a $L_{\mathrm{sz}}$ normalized cross-shore coordinate, where $L_{\mathrm{sz}}$ is time varying and has a time average of $96( \pm 41) \mathrm{m}$. At the surface, the three metrics are consistently ( $>70 \%$ of the time) elevated in the WW run relative to NW out to $5 L_{\mathrm{sz}}$ offshore. At $4 L_{\mathrm{sz}}$ offshore, a location relatively far offshore, metrics are enhanced in the WW run over the entire water column although WW and NW metrics are more similar near the bed. In a fixed coordinate as used for eddy transport analysis, the eddy cross-shore velocity squared correlation between WW and NW runs is near zero within $0.2 \mathrm{~km}$ of shore, and is $<0.5$ out to $1.2 \mathrm{~km}$ offshore or 12 timeaveraged $L_{\mathrm{sz}}$. These results indicate that the transport and dispersion of tracers (e.g., heat, larvae, and pollutants) across the inner shelf will be significantly different in the WW relative to NW runs.
The relative strength of the WW and NW metrics within the inner shelf is also affected by the shelf alongshore flows, as the WW and NW vorticity is more likely to be similar for stronger shelf alongshore flows. The phase-averaged wave model used here has bathymetrically controlled and shear instability induced rip currents, but does not have wave group or finite crest length breaking induced rip currents. Thus, surfzone effects on the inner shelf flow variability are likely underestimated here. Other coastal regions experience much larger incident waves than in this simulation, which will result in surfzone impacts that extend much farther offshore, distances multiple grid points of realistic ocean models that do not include waves. To model the realistic transport and dispersion of tracers (e.g., larvae, pollutants) across the inner shelf, wave-forced surfzone processes need to be included.

Acknowledgments. This work was supported by the National Science Foundation (OCE-1459389) as part of the CrossSurfzone/Inner-shelf Dye Exchange (CSIDE) experiment. Additional support is provided by the National Science Foundation under Grant OCE-1924005. Any opinions, findings, and conclusions or recommendations expressed in this material are those of the author(s) and do not necessarily reflect the views of the National Science Foundation. Additional funding is through the Environmental Protection Agency through the North American Development Bank, however it does not necessarily reflect the policies, actions or positions of the U.S. EPA or NADB. This work used the Extreme Science and Engineering Discovery Environment (XSEDE), which is supported by National Science Foundation (ACI-1548562). The numerical simulations were performed on the comet cluster at the San Diego Super Computer Center through XSEDE allocation TG-OCE180013. NOAA provided the NAM atmospheric forcing fields and the bathymetry. SIO Coastal Data Information Program provided wave forcing. Ganesh Gopalakrishnan and Bruce Cornuelle provided CASE model solutions for outer grid boundary conditions which are available online (http://ecco.ucsd.edu/case.html). We also appreciate extra support from the Tijuana River National Estuarine Research Reserve and the Southern California Coastal Ocean Observing System. Derek Grimes, Angelica Rodriguez, and Elizabeth Brasseale provided useful feedback on this work. This work is inspired by and dedicated to the memory of our dear friend and colleague Nirnimesh Kumar.

\section{REFERENCES}

Apotsos, A., B. Raubenheimer, S. Elgar, and R. T. Guza, 2008: Wave-driven setup and alongshore flows observed onshore of a submarine canyon. J. Geophys. Res., 113, C07025, https:// doi.org/10.1029/2007JC004514.

Austin, J. A., and S. J. Lentz, 2002: The inner shelf response to wind-driven upwelling and downwelling. J. Phys. Oceanogr., 32, 2171-2193, https://doi.org/10.1175/1520-0485(2002)032<2171: TISRTW >2.0.CO;2.

Battjes, J. A., 1988: Surf-zone dynamics. Annu. Rev. Fluid Mech., 20, 257-291, https://doi.org/10.1146/annurev.fl.20.010188.001353. - and M. J. F. Stive, 1985: Calibration and verification of a dissipation model for random breaking waves. J. Geophys. Res., 90, 9159-9167, https://doi.org/10.1029/JC090iC05p09159. 
Booij, N., R. C. Ris, and L. H. Holthuijsen, 1999: A third-generation wave model for coastal regions: 1 . Model description and validation. J. Geophys. Res., 104, 7649-7666, https://doi.org/ 10.1029/98JC02622.

Brink, K., 2016: Cross-shelf exchange. Annu. Rev. Mar. Sci., 8, 5978, https://doi.org/10.1146/annurev-marine-010814-015717.

Brown, J. A., J. H. MacMahan, A. J. H. M. Reniers, and E. B. Thornton, 2015: Field observations of surf zone-inner shelf exchange on a rip-channeled beach. J. Phys. Oceanogr., 45, 2339-2355, https://doi.org/10.1175/JPO-D-14-0118.1.

Castelao, R., R. Chant, S. Glenn, and O. Schofield, 2010: The effects of tides and oscillatory winds on the subtidal inner-shelf cross-shelf circulation. J. Phys. Oceanogr., 40, 775-788, https:// doi.org/10.1175/2009JPO4273.1.

Castelle, B., and G. Coco, 2013: Surf zone flushing on embayed beaches. Geophys. Res. Lett., 40, 2206-2210, https://doi.org/ 10.1002/grl.50485.

_- A. Reniers, and J. MacMahan, 2014: Bathymetric control of surf zone retention on a rip-channelled beach. Ocean Dyn., 64, 1221-1231, https://doi.org/10.1007/s10236-014-0747-0.

Clark, D. B., S. Elgar, and B. Raubenheimer, 2012: Vorticity generation by short-crested wave breaking. Geophys. Res. Lett., 39, L24604, https://doi.org/10.1029/2012GL054034.

Dalrymple, R., J. MacMahan, A. J. Reniers, and V. Nelko, 2011: Rip currents. Annu. Rev. Fluid Mech., 43, 551-581, https:// doi.org/10.1146/annurev-fluid-122109-160733.

Dauhajre, D. P., J. C. McWilliams, and Y. Uchiyama, 2017: Submesoscale coherent structures on the continental shelf. J. Phys. Oceanogr., 47, 2949-2976, https://doi.org/10.1175/ JPO-D-16-0270.1.

,-- , and L. Renault, 2019: Nearshore Lagrangian connectivity: Submesoscale influence and resolution sensitivity. J. Geophys. Res. Oceans, 124, 5180-5204, https://doi.org/ 10.1029/2019JC014943.

Davis, K. A., R. S. Arthur, E. C. Reid, J. S. Rogers, O. B. Fringer, T. M. DeCarlo, and A. L. Cohen, 2020: Fate of internal waves on a shallow shelf. J. Geophys. Res. Oceans, 125, e2019JC015377, https://doi.org/10.1029/2019JC015377.

Feddersen, F., 2012: Scaling surf zone turbulence. Geophys. Res. Lett., 39, L18613, https://doi.org/10.1029/2012GL052970.

— 2014: The generation of surfzone eddies in a strong alongshore current. J. Phys. Oceanogr., 44, 600-617, https://doi.org/ 10.1175/JPO-D-13-051.1.

— Alongshore uniformity. J. Geophys. Res., 108, 3006, https:// doi.org/10.1029/2001JC001293.

$\longrightarrow,-$, S. Elgar, and T. H. C. Herbers, 1998: Alongshore momentum balances in the nearshore. J. Geophys. Res., 103, 15 667-15 676, https://doi.org/10.1029/98JC01270.

Fewings, M., S. J. Lentz, and J. Fredericks, 2008: Observations of cross-shelf flow driven by cross-shelf winds on the inner continental shelf. J. Phys. Oceanogr., 38, 2358-2378, https:// doi.org/10.1175/2008JPO3990.1.

Ganju, N. K., S. J. Lentz, A. R. Kirincich, and J. T. Farrar, 2011: Complex mean circulation over the inner shelf south of Martha's Vineyard revealed by observations and a highresolution model. J. Geophys. Res., 116, C10036, https:/doi.org/ 10.1029/2011JC007035.

Grimes, D. J., and F. Feddersen, 2021: The self-similar stratified inner-shelf response to transient rip-current induced mixing. J. Fluid Mech., 915, A82, https://doi.org/10.1017/jfm.2021.140.

,$- \ldots$, S. N. Giddings, and G. Pawlak, 2020a: Cross-shore deformation of a surfzone-released dye plume by an internal tide on the inner shelf. J. Phys. Oceanogr., 50, 35-54, https:// doi.org/10.1175/JPO-D-19-0046.1.

_ _ _ and N. Kumar, 2020b: Tracer exchange across the stratified inner-shelf driven by transient rip-currents and diurnal surface heat fluxes. Geophys. Res. Lett., 47, e2019GL086501, https://doi.org/10.1029/2019GL086501.

Haller, M. C., R. A. Dalrymple, and I. A. Svendsen, 2002: Experimental study of nearshore dynamics on a barred beach with rip channels. J. Geophys. Res., 107, 3061, https://doi.org/ 10.1029/2001JC000955.

Hally-Rosendahl, K., F. Feddersen, and R. T. Guza, 2014: Crossshore tracer exchange between the surfzone and inner-shelf. J. Geophys. Res. Oceans, 119, 4367-4388, https://doi.org/ 10.1002/2013JC009722.

$\longrightarrow,-$, D. B. Clark, and R. T. Guza, 2015: Surfzone to inner-shelf exchange estimated from dye tracer balances. J. Geophys. Res. Oceans, 120, 6289-6308, https://doi.org/10.1002/2015JC010844.

Horwitz, R., and S. J. Lentz, 2014: Inner-shelf response to crossshelf wind stress: The importance of the cross-shelf density gradient in an idealized numerical model and field observations. J. Phys. Oceanogr., 44, 86-103, https://doi.org/10.1175/ JPO-D-13-075.1.

Johnson, D., and C. Pattiaratchi, 2006: Boussinesq modelling of transient rip currents. Coast. Eng., 53, 419-439, https://doi.org/ 10.1016/j.coastaleng.2005.11.005.

Kirincich, A. R., 2016: The occurrence, drivers, and implications of submesoscale eddies on the Martha's Vineyard inner shelf. J. Phys. Oceanogr., 46, 2645-2662, https://doi.org/10.1175/ JPO-D-15-0191.1.

—, S. J. Lentz, and J. A. Barth, 2009: Wave-driven inner-shelf motions on the Oregon coast. J. Phys. Oceanogr., 39, 29422956, https://doi.org/10.1175/2009JPO4041.1.

Kumar, N., and F. Feddersen, 2017a: The effect of Stokes drift and transient rip currents on the inner shelf. Part I: No stratification. J. Phys. Oceanogr., 47, 227-241, https://doi.org/10.1175/ JPO-D-16-0076.1.

$\longrightarrow$, and,$- 2017 \mathrm{~b}$ : The effect of stokes drift and transient rip currents on the inner shelf. Part II: With stratification. J. Phys. Oceanogr., 47, 243-260, https://doi.org/10.1175/JPO-D-16-0077.1. - , and - 2017c: A new offshore transport mechanism for shoreline-released tracer induced by transient rip currents and stratification. Geophys. Res. Lett., 44, 2843-2851, https:// doi.org/10.1002/2017GL072611.

, G. Voulgaris, J. C. Warner, and M. Olabarrieta, 2012: Implementation of the vortex force formalism in the coupled ocean-atmosphere-wave-sediment transport (COAWST) modeling system for inner shelf and surf zone applications. Ocean Modell., 47, 65-95, https://doi.org/10.1016/j.ocemod.2012.01.003.

_, F. Feddersen, Y. Uchiyama, J. McWilliams, and W. O'Reilly, 2015: Midshelf to surfzone coupled ROMS-SWAN model data comparison of waves, currents, and temperature: Diagnosis of subtidal forcings and response. J. Phys. Oceanogr., 45, 14641490, https://doi.org/10.1175/JPO-D-14-0151.1.

,,- S. Suanda, Y. Uchiyama, and J. McWilliams, 2016: Midto inner-shelf coupled ROMS-SWAN model-data comparison of currents and temperature: Diurnal and semidiurnal variability. J. Phys. Oceanogr., 46, 841-862, https://doi.org/ 10.1175/JPO-D-15-0103.1.

—, S. H. Suanda, J. A. Colosi, K. Haas, E. Di Lorenzo, A. J. Miller, and C. A. Edwards, 2019: Coastal semidiurnal internal tidal incoherence in the Santa Maria Basin, California: Observations and model simulations. J. Geophys. Res. Oceans, 124, 5158-5179, https://doi.org/10.1029/2018JC014891. 
Largier, J. L., 2020: Upwelling bays: How coastal upwelling controls circulation, habitat, and productivity in bays. Annu. Rev. Mar. Sci., 12, 415-447, https://doi.org/10.1146/annurev-marine-010419-011020.

Lentz, S. J., 2001: The influence of stratification on the wind-driven cross-shelf circulation over the North Carolina shelf. J. Phys. Oceanogr., 31, 2749-2760, https://doi.org/10.1175/1520-0485(2001) $031<2749$ :TIOSOT $>2.0 . \mathrm{CO} ; 2$.

- and M. R. Fewings, 2012: The wind- and wave-driven innershelf circulation. Annu. Rev. Mar. Sci., 4, 317-343, https:// doi.org/10.1146/annurev-marine-120709-142745.

- M. Fewings, P. Howd, J. Fredericks, and K. Hathaway, 2008: Observations and a model of undertow over the inner continental shelf. J. Phys. Oceanogr., 38, 2341-2357, https://doi.org/ 10.1175/2008JPO3986.1.

Long, J. W., and H. Özkan Haller, 2005: Offshore controls on nearshore rip currents. J. Geophys. Res., 110, C12007, https:// doi.org/10.1029/2005JC003018.

—_, and H. T. Özkan-Haller, 2009: Low-frequency characteristics of wave group-forced vortices. J. Geophys. Res., 114, C08004, https://doi.org/10.1029/2008JC004894.

Longuet-Higgins, M. S., 1970: Longshore currents generated by obliquely incident sea waves: 1. J. Geophys. Res., 75, 67786789, https://doi.org/10.1029/JC075i033p06778.

MacMahan, J., and Coauthors, 2010: Mean Lagrangian flow behavior on an open coast rip-channeled beach: A new perspective. Mar. Geol., 268, 1-15, https://doi.org/10.1016/j.margeo.2009.09.011.

Monismith, S. G., A. Genin, M. A. Reidenbach, G. Yahel, and J. R. Koseff, 2006: Thermally driven exchanges between a coral reef and the adjoining ocean. J. Phys. Oceanogr., 36, 13321347, https://doi.org/10.1175/JPO2916.1.

Moulton, M., S. Elgar, B. Raubenheimer, J. C. Warner, and N. Kumar, 2017: Rip currents and alongshore flows in single channels dredged in the surf zone. J. Geophys. Res. Oceans, 122, 3799-3816, https://doi.org/10.1002/2016JC012222.

—, C. Chickadel, and J. Thomson, 2021: Warm and cool nearshore plumes connecting the surfzone to the inner shelf. Geophys. Res. Lett., 48, e2020GL091675, https://doi.org/10.1029/ 2020GL091675.

Noyes, T. J., R. T. Guza, F. Feddersen, S. Elgar, and T. H. C. Herbers, 2005: Model-data comparisons of shear waves in the nearshore. J. Geophys. Res., 110, C05019, https://doi.org/ 10.1029/2004JC002541.

O'Dea, A., N. Kumar, and M. C. Haller, 2021: Simulations of the surf zone eddy field and cross-shore exchange on a non-idealized bathymetry. J. Geophys. Res. Oceans, 126, e2020JC016619, https://doi.org/10.1029/2020JC016619.

O'Reilly, W., C. Olfe, J. Thomas, R. Seymour, and R. Guza, 2016: The California coastal wave monitoring and prediction system. Coast. Eng., 116, 118-132, https://doi.org/10.1016/j.coastaleng.2016.06.005.

Özkan-Haller, H., and J. T. Kirby, 1999: Nonlinear evolution of shear instabilities of the longshore current: A comparison of observations and computations. J. Geophys. Res., 104, $25953-$ 25 984, https://doi.org/10.1029/1999JC900104.

Peregrine, D., 1998: Surf zone currents. Theor. Comput. Fluid Dyn., 10, 295-309, https://doi.org/10.1007/s001620050065.

Reniers, A. J. H. M., J. A. Roelvink, and E. B. Thornton, 2004: Morphodynamic modeling of an embayed beach under wave group forcing. J. Geophys. Res., 109, C01030, https://doi.org/ 10.1029/2002JC001586.

— J. H. MacMahan, E. B. Thornton, and T. P. Stanton, 2007: Modeling of very low frequency motions during RIPEX. J. Geophys. Res., 112, C07013, https://doi.org/10.1029/ 2005JC003122. $-,-,-\longrightarrow,-$ M. Henriquez, J. W. Brown, J. A. Brown, and E. Gallagher, 2009: Surf zone surface retention on a rip-channeled beach. J. Geophys. Res., 114, C10010, https:// doi.org/10.1029/2008JC005153.

Romero, L., Y. Uchiyama, J. C. Ohlmann, J. C. McWilliams, and D. A. Siegel, 2013: Simulations of nearshore particle-pair dispersion in Southern California. J. Phys. Oceanogr., 43, 1862-1879, https://doi.org/10.1175/JPO-D-13-011.1.

Ruessink, B. G., J. R. Miles, F. Feddersen, R. T. Guza, and S. Elgar, 2001: Modeling the alongshore current on barred beaches. J. Geophys. Res., 106, 22 451-22 463, https://doi.org/10.1029/ 2000JC000766.

Seymour, R. J., J. O. Thomas, and D. Castel, 2016: CDIP wave observations during a strong El Niño year. Shore Beach, 84, 36-37.

Shchepetkin, A., and J. McWilliams, 2005: The regional oceanic modeling system (ROMS): A split-explicit, free-surface, topographyfollowing-coordinate oceanic model. Ocean Modell., 9, 347404, https://doi.org/10.1016/j.ocemod.2004.08.002.

Sinnett, G., F. Feddersen, A. J. Lucas, G. Pawlak, and E. Terrill, 2018: Observations of nonlinear internal wave run-up to the surfzone. J. Phys. Oceanogr., 48 531-554, https://doi.org/ 10.1175/JPO-D-17-0210.1.

Spydell, M., and F. Feddersen, 2009: Lagrangian drifter dispersion in the surf zone: Directionally spread, normally incident waves. J. Phys. Oceanogr., 39, 809-830, https://doi.org/10.1175/ 2008JPO3892.1.

Spydell, M. S., F. Feddersen, and S. Suanda, 2019: Inhomogeneous turbulent dispersion across the nearshore induced by surfzone eddies. J. Phys. Oceanogr., 49, 1015-1034, https://doi.org/ 10.1175/JPO-D-18-0102.1.

Suanda, S. H., and F. Feddersen, 2015: A self-similar scaling for cross-shelf exchange driven by transient rip currents. Geophys. Res. Lett., 42, 5427-5434, https://doi.org/10.1002/ 2015 GL063944.

_ - , and N. Kumar, 2017: The effect of barotropic and baroclinic tides on coastal stratification and mixing. J. Geophys. Res. Oceans, 122, 10 156-10 173, https://doi.org/ 10.1002/2017JC013379.

- — - M. S. Spydell, and N. Kumar, 2018: The effect of barotropic and baroclinic tides on three-dimensional coastal dispersion. Geophys. Res. Lett., 45, 11235-11246, https:// doi.org/10.1029/2018GL079884.

Uchiyama, Y., J. C. McWilliams, and C. Akan, 2017: Threedimensional transient rip currents: Bathymetric excitation of low-frequency intrinsic variability. J. Geophys. Res. Oceans, 122, 5826-5849, https://doi.org/10.1002/2017JC013005.

Warner, J. C., B. Armstrong, R. He, and J. B. Zambon, 2010: Development of a Coupled Ocean-Atmosphere-Wave-Sediment Transport (COAWST) modeling system. Ocean Modell., 35, 230244, https://doi.org/10.1016/j.ocemod.2010.07.010.

Winter, G., A. van Dongeren, M. de Schipper, and J. van Thiel de Vries, 2014: Rip currents under obliquely incident wind waves and tidal longshore currents. Coast. Eng., 89, 106-119, https:// doi.org/10.1016/j.coastaleng.2014.04.001.

$\mathrm{Wu}$, X., F. Feddersen, S. N. Giddings, N. Kumar, and G. Gopalakrishnan, 2020: Mechanisms of mid- to outer-shelf transport of shoreline-released tracers. J. Phys. Oceanogr., 50, 1813-1837, https://doi.org/10.1175/JPO-D-19-0225.1.

- — , and — 2021: Characteristics and dynamics of density fronts over the inner to mid-shelf under weak wind conditions. J. Phys. Oceanogr., 51, 789-808, https://doi.org/10.1175/JPOD-20-0162.1. 